\title{
ANALISA YURIDIS TERHADAP SISTEM KAMERAL MAJELIS PERMUSYAWARATAN RAKYATSESUDAH PERUBAHAN UNDANG-UNDANG DASAR 1945
}

\author{
Oleh: Fernando Silalahi \\ Rupertus Arvinci Ngabut \\ fernando.irsh@yahoo.com \\ Universitas Kristen Indonesia, Jakarta, Indonesia
}

\begin{abstract}
In the life of a state that longs for a political justice, surely in the Basic Law or the Constitution in the country the inventor of his ideas and / or its founders have included a power sharing system that seeks to re ect political justice. If it must be connected with the form of the state, in fact this idea remains rooted in political justice. In the distribution of power, which according to John Locke is divided into legislative power, executive power, and judicial power, there must be authority that is balanced with each other and not overlapping. This was stated by John Locke so that power is not centralized within one institution, thereby reducing the risk of abuse and creating a democratic state.
\end{abstract}

Keywords: political justice; legislative power; judicial power; democratic state.

\section{Pendahuluan}

Dinamika ketatanegaraan Indonesia saat ini mengalami turbulensi politik dan hukum yang cukup bias. Rapuhnya sistem kameral merupakan bias yang muncul pasca perubahan konstitusi. Indonesia saat ini belum ada kejelasan dalam menganut sistem kameral, baik itu unikameral, bikameral, maupun trikameral.Konsep bikameral yang distrukturkan dan dikonstruksikan dalam Undang-Undang Dasar 1945 tentang lembaga perwakilan memperjelas tipologi lembaga perwakilandiIndonesia.Tetapi desain dan penataan lembaga perwakilan yang ditetapkan ini sudah bermasalah dari awal karena yang dihasilkan adalah hubungan lembaga perwakilan yang tidak jelas, baik itu menyangkut MPR, DPR, dan DPD ${ }^{1}$.

Di Indonesia, kekuasaan legislatif dibagi dalam kekuasaan yang diampu oleh DPR dan DPD yang juga menjadi bagian dalam keanggotaan MPR sebagaimana yang ditetapkan oleh Undang-Undang Dasar 1945. Dengan adanya DPR dan DPD dalam kekuasan legislatif ini, dapat dilihat bahwasannya Indonesia menganut sistem bikameral yang mana kekuasaan legislatif ini terbagi dalam dua kamar.Sistem bikameral merupakan sistem badan perwakilan yang terdiri dari dua unsur yang sama-sama menjalankan segala wewenang badan perwakilan.Dua unsur tersebut memiliki tugas pokok, fungsi, hak, dan kewajiban secara berimbang.Idealnya, tidak ada berat sebelah dan keduanya bekerja secara kooperatif .

Di Indonesia telah beberapa kali terjadi perubahan struktur parlemen seiring dengan pergantian dan perubahan UUD yang berlaku di Indonesia.Pada saat Indonesia berbentuk negara serikat pada tahun 1949, maka UUD yang digunakan adalah Konstitusi RIS. Dalam Konstitusi RIS ini, selain DPR, daerah-daerah bagian juga diberi wakil dalam parlemen (Senat). Setelah Indonesia kembali ke negara kesatuan, maka digunakan UUDS RI dan Senat RIS dihapuskan karenadaerah-daerahbagian tidak ada lagi dalam sistem negara kesatuan. Walaupun UUD 1945 menganut sistem yang sama dengan bentuk negara dalam UUDS RI, yaitu negara kesatuan, terdapat perbedaan 
dalam kedua UUD tersebut berkaitan dengan struktur parlemen perubahan terjadi pada MPR dan DPR serta dibentuk suatu lembaga baru yaitu DPD. DPD dibentuk dalam rangka pelaksanaan gagasan bikameral dalam pembahasan perubahan UUD $1945 .^{3}$

Sistem parlemen Indonesia yang tercermin dalam lembaga MPR terdiri dari dua kamar yaitu DPR dan DPD. Di Indonesia, DPD memiliki kewenangan yang terbatas dibandingkan dengan DPR, meski keduanya memiliki masa jabatan periode yang sama yaitu 5 tahun. Dalam kaitannya dengan posisi DPD, menurut ketentuan Pasal 20 Ayat (1) UUD 1945 perubahan pertama oleh MPR tahun 1999, DPR adalah lembaga yang berwenang membentuk undang-undang, sedangkan DPD pada perubahan ketiga tahun 2001 kewenangannya terbatas untuk memberikan pertimbangan usul dan saran kepada DPR, dan mengawasi pelaksanaan undang- undang tertentu. Peran sebagai ko-pembahas dilakukan oleh DPD dalam sidang DPR bersama pemerintah yang didahului oleh pembahasan dalam sidang DPD. Dalam Pasal 20 ayat (2) ditegaskan, "setiap rancangan undang-undang dibahas oleh Dewan Perwakilan Rakyat dan Presiden untuk...".

Berdasarkan hal-hal yang telah diuraikan di atas, penulis hendak mengulas tentang sistem lembaga perwakilan rakyat, apakah menganut bikameral atau trikameral melihat posisi MPR pasca perubahan bukan lagi sebagai Lembaga Tertinggi Negara. Penulis menuangkan ulasan mengenai hal-hal di atas dalam tulisan yang berjudul: "ANALISA YURIDIS TERHADAP SISTEM KAMERAL MAJELIS PERMUSYAWARATAN RAKYAT SETELAH PERUBAHAN UNDANG- UNDANG DASAR 1945".

Berdasarkan latar belakang yang telah dikemukakan sebelumnya, terdapat dua pertanyaan yang akan dikaji dan dicari jawabannya dalam penelitian ini, yaitu bagaimana sistem kameral yang dianut Majelis Permusyawaratan Rakyat sesudah perubahan UndangUndang Dasar1945 serta bagaimana sistem kameral yang dianut Majelis Permusyawaratan Rakyat sesudah perubahan dilihat dari kedudukan DPR dan DPD saat ini, sehingga kita mengetahui sistemkameral yang dianut Majelis Permusyawaratan Rakyat sesudah perubahan Undang-Undang Dasar1945.

\section{Perkembangan Sistem Parlemen diIndonesia}

Sering kali dipahami bahwa Fungsi legislasi hanya terkait dengan fungsi undang-undang dalam pengertian yang sempit.Karena itu, yang biasa dipahami sebagai

lembaga legislatif berdasarkan UUD 1945 pasca reformasi adalah hanya DPR dan DPD saja.Bahkan, banyak pula tokoh-tokoh politik yang memahaminya lebih sempit lagi, yaitu bahwa lembaga yang mempunyai kewenangan langsung dibidang pembuatan undang-undang itu hanya DPR, sedangkan DPD hanya berfungsi sebagai advisory council terhadap fungsi DPR.

Prinsip kedaulatan yang berasal dari rakyat selama ini (pra perubahan) diwujudkan melalui Majelis Permusyawaratan Rakyat yang merupakan penjelmaan seluruh rakyat Indonesia, pelaku sepenuhnya kedaulatan rakyat dan yang diakui sebagai lembaga tertinggi negara dengan kekuasaan yang tidak terbatas.Dari majelis inilah kekuasaan rakyat dibagi-bagikan secara vertikal ke dalam lembaga-lembaga tinggi negara yang ada dibawahnya.Oleh karena itu, prinsip yang dianut dalam model ini disebut prinsip pembagian kekuasaan (division or distribution ofpower).

Akan tetapi, dalam Undang-Undang Dasar 1945 (pasca perubahan), kedaulatan rakyat ditentukan dan dibagikan secara horizontal dengan cara memisahkannya (separation of power) menjadi kekuasaan yang dinisbatkan sebagai fungsilembaga-lembaganegarayangsederajatdansalingmengendalikansatusamalain berdasarkan prinsip checks and balances ${ }^{4}$.Cabang kekuasaan legislatif tetap berada di Majelis Permusyawaratan Rakyat, tetapi majelis ini terdiri dari dua lembaga perwakilan yang sederajat dengan lembaga negara lainnya.

Lebih lanjut dalam bukunya yang berjudul Konstitusi dan Konstitusionalisme Indonesia, Prof. Dr. Jimly Asshiddiqie menyatakan bahwa Majelis Permusyawaratan Rakyat merupakan lembaga yang berdiri sendiri di samping fungsinya sebagai rumah penjelmaan seluruh seluruh rakyat yang terdiri dari Dewan Perwakilan Rakyat dan Dewan Perwakilan Daerah. Prinsip perwakilan

\footnotetext{
3 Jimly Asshidiqie, 2014, Konstitusi \& Konstitusionalisme Indonesia, Sinar Grafika, Jakarta, hlm. 60

4 Ibid
} 
daerah dalam Dewan Perwakilan Daerah ini harus dibedakan hakikatnya dari prinsip perwakilan Rakyat dalam Dewan Perwakilan Rakyat. Maksudnya ialah agar seluruh aspirasi rakyat benar-benar dapat dijelmakan ke dalam Majelis Permusyawaratan Rakyat.

Dalam pandangan Jimly Asshiddiqie, perbincangan teoritis mengenai struktur organisasi parlemen ini biasanya dikenal adanya dua sistem yaitu sistem unikameral dan bikameral.Sistem yang pertama terdiri atas satu kamar, sedangkan yang kedua mempunyai dua kamar yang masing-masing mempunyai fungsi sendiri-sendiri.Selama berabad-abad, kedua tipe struktur pengorganisasian demikian inilah yang biasa dikembangkan dimana-dimana.Karena itu, dalam berbagai literatur hukum tata negara maupun literatur ilmupolitik, kedua sistem inilah yang biasa dikenal ${ }^{5}$.

\section{Teori Kameral}

Sistem kamar (unikameral, bikameral, dan trikameral) dalam lembaga perwakilan rakyatefektifitasnya ditentukan oleh perimbangan kewenangan antar- kamar dalam pelaksanaan fungsi parlemen seperti fungsi legislasi, anggaran, kontrol, representasi, dan rekrutmen politik.Dari fungsi tersebut, perimbangan dalam fungsi legislasi menjadi faktor utama.

International Comission of Jurist merumuskan sistem politik yang demokratis sebagai suatu bentuk pemerintah dimana hak untuk membuat keputusankeputusan politik diselenggarakan oleh warga negara melalui wakil-wakil yang dipilih oleh mereka dan yang bertanggungjawab kepada mereka melalui suatu proses pemilihan yang bebas. Dalam sistem pemerintah demokratis yang dilaksanakan dengan sistem perwakilan, maka keberadaan lembaga perwakilan rakyat dipandang sebagai suatu keniscayaan dalam penyelenggaraan sistem pemerintahan ini.Lembaga negara ini merupakan badan yang berwenang sebagai pelaksana kekuasaan negara dalam hal menentukan kebijakan umum yang mengikat seluruh rakyat ${ }^{6}$. 5 Jimly Asshiddiqie, Konsolidasi Naskah UUD 1945 Setelah Perubahan Keempat, Jakarta:Pusat Studi Hukum Tata Negara FHUI, 2002, hlm. 33.

6 Pusat Studi Hukum dan Kebijakan, 2000, Semua Harus Terwakili; Studi mengenai Reposisi MPR, DPR, dan Lembaga Kepresidenan di Indonesia, PSHK, Jakarta, hal.3940.
Lembaga perwakilan atau lembaga legislatif, saat ini di banyak negara disebut dengan nama Parlemen.

Perbincangan teoritis mengenai struktur organisasi parlemen ini biasanya dikenal adanya dua sistem, yaitu sistem unikameral dan bikameral. Yang pertamaterdiri atas satu kamar, sedangkan yang kedua mempunyai dua kamar yang masing- masing mempunyai fungsi sendiri-sendiri.Selama berabad-abad, kedua tipe struktur pengorganisasian demikian inilah yang biasa dikembangkan dimana-mana.Karena itu dalam berbagai literatur hukum tata negara maupun literatur ilmu politik, kedua sistem inilah yang biasadikenal.

\section{SistemUnikameral}

Sistem unikameral atau sistem satu kamar adalah sistem pemerintahan yang hanya memiliki satu kamar pada parlemen atau lembaga legislatif.Banyak negara yang menggunakan sistem satu kamar seringkali adalah negara kesatuan yang kecil dan homogen dan menganggap sebuah majelis tinggi atau kamar kedua tidak perlu.

Beberapa keuntungan dalam sistem legislatif unikameral, antara lain:Kemungkinan untuk dapat cepat meloloskan Undang-Undang (karena hanya satu badan yang diperlukan untuk mengadopsi Rancangan Undang-Undang sehingga tidak perlu lagi menyesuaikan dengan usulan yangberbeda-beda).Tanggung jawab lebih besar (karena anggota legislatif tidak dapat menyalahkan majelis lainnya apabila suatu UndangUndang tidak lolos, atau bila kepentingan warga negaraterabaikan).Lebih sedikit anggota terpilih sehingga lebih mudah bagi masyarakat untuk memantau kepentingan mereka

\section{Sistem Bikameral}

PengertianSistem Bikameral adalah wujud institusional dari lembaga perwakilan atau parlemen sebuah negara yang terdiri atas dua kamar (majelis).Majelis yang anggotanya dipilih dan mewakili rakyat yang berdasarkan jumlah penduduk secara generik disebut majelis pertama atau majelis rendah. Majelis yang anggotanya dipilihatau diangkat dengan dasar lain (bukan berdasarkan jumlah penduduk), disebut majelis kedua atau majelis tinggi.Ada dua alasan mengapa para penyusun konstitusi memilih sistem bikameral. 
Pertama adalah untuk membangun sebuah mekanisme pengawasan dan keseimbangan (checks and balances) serta untuk pembahasan sekali lagi dalam bidang legislatif.Alasan kedua adalah untuk membentuk perwakilan untuk menampung kepentingan tertentu yang biasanya tidak cukup terwakili oleh majelis pertama. Secara khusus, bikameralisme telah digunakan untuk menjamin perwakilan yang memadai untuk daerahdaerah di dalam lembaga legislatif.Pelembagaan fungsi legislature itulah yang disebut parlemen.Di berbagai negara ada yang melembagakannya dalam satu forum saja (unicameral atau monocameral), ada pula yang dua forum (bicameral).Bahkan ada pula negara-negara yang mempunyai struktur parlemen multi kameral atau terdiri atas lebih dari dua kamarataulebihdariduainstitusi.SalahsatunyaadalahIndonesiayangmempunyaitiga institusi atau tiga forum parlemen sekaligus, yaitu DPR, DPD, dan MPR. DPRmerupakan lembaga perwakilan politik (political representation), DPR merupakan perwakilan daerah (regional representation), sedangkan MPR merupakan penjelmaan keseluruhan rakyat, baik dari segi politik maupun kedaerahan.MPR menetapkan UUD sebagai kebijakan tertinggi.

Basis argumentasi yang mendukung bahwa sistem parlemen Indonesia menganut sistem trikameralisme adalah susunan anggota MPR berubah secara struktural karena dihapuskannya keberadaan Utusan Golongan yang mencerminkan prinsip perwakilan fungsional (functional representation) dari unsur keanggotaan MPR.Dengan demikian, anggota MPR hanya terdiri atas anggota Dewan Perwakilan Rakyat (DPR) yang mencerminkan prinsip perwakilan politik (political representation) dan anggota Dewan Perwakilan Daerah (DPD) yang mencerminkan prinsip perwakilan daerah (regionalrepresentation).Majelis ini tidak lagi berfungsi sebagai 'supreme body' yang memiliki kewenangan tertinggi dan tanpa kontrol dan karena itu kewenangannyapun mengalami perubahanperubahan mendasar.

Sebelum diadakan perubahan UUD, MPR, memiliki kewenangan, yaitu: (a) Menetapkan Undang- Undang Dasar dan mengubah Undang- Undang Dasar, (b) menetapkan garis- garis besar haluan negara, (c) Memilih Presiden dan Wakil Presiden, (d) meminta dan menilai pertanggungjawaban Presiden.

Setelah diadakan Perubahan Undang-Undang Dasar 1945, kewenangan MPR berubahmenjadi: a) menetapkan Undang-Undang Dasar dan/atau perubahanUndang-Undang Dasar, b) melantik Presiden dan WakilPresiden, c) memberhentikan Presiden dan/ atau Wakil Presiden,d) menetapkan Presiden dan/atau Wakil Presiden Pengganti sampai terpilihnya Presiden dan/atau Wakil Presiden sebagaimanamestinya. Diadopsinya prinsip pemisahan kekuasaan (separation of power)secarategas antara fungsi legislatif dan eksekutif dalam perubahan pasal 5 ayat (1) juncto pasal 20 ayat (1) dalam perubahan pertama UndangUndang Dasar 1945 tidak lagi menganut sistem MPR berdasarkan prinsip 'supremasi parlemen' dan sistem pembagian kekuasaan (distribution of power) oleh lembaga tertinggi MPR kelembaga-lembaga negara dibawahnya. Diadopsinya prinsip pemilihan Presiden dan Wakil Presiden dalam satu paket secara langsung oleh rakyat dalam ketentuan pasal $6 \mathrm{~A}$ ayat (1) perubahan ketiga Undang-Undang Dasar 1945 yang sekaligus dimaksudkan untuk memperkuat dan mempertegas sistem pemerintahan presidensiil dalam Undang-Undang Dasar 1945. Dengan sistem pemilihan langsung oleh rakyat, maka konsep dan sistem pertanggungjawaban Presiden tidak lagi dilakukan kepada Majelis Permusyaratan Rakyat, kedaulatan yang ada di tangan rakyat itu sepanjang menyangkut fungsi legistatif, dilakukan oleh MPR yang terdiri dari dua kamar dewan, sedangkan dalam bidang eksekutif dilakukan oleh Presiden dan Wakil Presiden sebagi satu paket kepemimpinan eksekutif yang dipilih langsung olehrakyat.

\section{TeoriKonstitusi}

Istilah konstitusi berasal dari bahasa Perancis (constituer) yang berarti membentuk.Pemakaian istilah konstitusi yang dimaksudkan ialah pembentukan suatu negara atau yang menyusun dan menyatakan suatu negara.Sedangkan istilah Undang-Undang Dasar merupakan terjemahan istilah yang dalam bahasa BelandanyaGronwet. Perkataan wet diterjemahkan ke dalam bahasa Indonesia sebagai undang- undang dan ground berarti tanah/dasar.Di negara-negara yang meng- 
gunakan bahasa Inggris sebagai bahasa nasional, dipakai istilah Constitution yang dalam bahasa Indonesia disebut konstitusi.Pengertian konstitusi dalam praktek dapat berarti lebih luas dari pada pengertian Undang-Undang Dasar, tetapi ada juga yang menyamakan dengan pengertian Undang-Undang Dasar.Berangkat dari beberapa pendapat para ahli tentang pengertian konstitusi dapatlah ditarik kesimpulan bahwa pengertian konstitusi meliputi konstitusi tertulis dan konstitusi tidak tertulis. Adapun batasan-batasannya dapat dirumuskan ke dalam pengertian sebagai berikut:

- Suatu kumpulan kaidah yang memberikan pembatasan kekuasaan kepada para penguasa.

- Suatu dokumen tentang pembagian tugas sekaligus petugasnya dari suatu sistempolitik.

- Suatu deskripsi dari lembaga-lembaganegara.

- Suatu deskripsi yang menyangkut masalah hakhak asasimanusia.

\section{Kedudukan, Fungsi, dan TujuanKonstitusi}

Konstitusi adalah hukum dasar yang dijadikan pegangan dalam penyelenggaraan suatu negara. Konstitusi dapat berupa hukum dasar yang tertulis yang lazim disebut Undang-Undang Dasar, dan dapat pula tidak tertulis.Di negara yang mendasarkan dirinya atas demokrasi konstitusional,Undang-Undang Dasar mempunyai fungsi yang khas, yaitu membatasi kekuasaan pemerintah sedemikian rupa, sehingga penyelenggaraan kekuasaan tidak bersifat sewenangwenang.Dengan demikian diharapkan hak-hak warga negara dapat terlindungi.Gagasan ini dinamakan konstitusionalisme.Usaha negara untuk mencapai tujuan masyarakat negaranya, di dalam konstitusi telah ditentukan bermacam-macam lembaga negara.Supaya tidak terjadi penyalahgunaan kekuasaan, kedudukan serta tugas dan wewenang masing-masing lembaga negara juga ditentukan.Hal ini berarti adanya pembatasan kekuasaan terhadap setiap lembaga politik.Pembatasan terhadap lembaga-lembaga tersebut meliputi duahal yaitu pembatasan kekuasaan meliputi isikekuasaannya serta pembatasan kekuasaan yang berkenaan dengan waktu dijalankannya kekuasaantersebut.

Pembatasan kekuasaan yang pertama mengandung arti, bahwa dalam konstitusi ditentukan tugas serta wewenang lembaga-lembaga negara.Bahkan terhadap lembaga-lembaga negara yang mempunyai kedudukan dan peranan penting dalam usaha pencapaian tujuan negara, dalam hal ini pemerintah, masih mendapat pengawasan dari lembaga permusyawaratanrakyat.

Pembatasan dalam arti kedua adalah pembatasan kekuasaan yang berkenaan dengan waktu dijalankannya kekuasaan tersebut dapat dijalankan.Hal ini berkenaan dengan masa jabatan masing-masing lembaga negara atau pejabatnya dalam menjalankan kekuasaannya.Dengan demikian, dalam waktu yang telah ditentukan harus dilakukan penggantian atau pembaruan si pejabat.

Superioritas konstitusi mempunyai daya ikat bukan saja bagi rakyat atau warga negara tetapi termasuk juga bagi para penguasa dan bagi badan pembuat konstitusi itusendiri. Konstitusi tidak boleh bertentangan dengan nilai-nilai universal dari etika moral. Oleh karena itu, dilihat dari sisi filosofi dari konstitusi, apabila aturan konstitusi bertentangan dengan etika moral, maka seharusnya konstitusi dikesampingkan.Kedudukan dan fungsi konstitusi dalam suatu negara ditentukan oleh ideologi yang melandasi negara tersebut.Berhubung dengan hal itu, konstitusi di jaman modern ini tidak hanya memuat aturan-aturan hukum, tetapi juga merumuskan prinsip-prinsip hukum, haluan negara dan patokan kebijaksanaan, yang kesemuanya selain berlaku untuk masyarakat secara umum, juga kesemuanya mengikat penguasa.

\section{Kedudukan dan Fungsi Majelis Per- musyawaratan Rakyat Setelah Amandemen Undang-Undang Dasar 1945}

KelembagaanMPR Setelah Amandemen Undang-Undang Dasar 1945

Dalam naskah asli Undang-Undang Dasar 1945, mengenai kelembagaan dalam Majelis Permusyawaratan Rakyat (MPR) diatur dalam Pasal 2 ayat (1) berbunyi "MajelisPermusyawaratan Rakyat terdiri atas anggota-anggota Dewan Perwakilan Rakyat, ditambah dengan utusan-utusan dari daerah-daerah dan golongan-golongan, menurut aturan yang ditetapkanundang-undang. Selain itu, mengenai MPR diatur pula dalam naskah asli Undang-Undang Dasar 1945 pasal 1 
ayat (2) yang berbunyi, Kedaulatan ada ditangan rakyat, dan dilakukan sepenuhnya oleh Majelis Permusyawaratan Rakyat. Selanjutnya Pasal 2 ayat (2) berbunyi, Majelis Permusyawaratan Rakyat bersidang sedikitnya sekali dalam lima tahun di ibu kota negara. Ayat (3) Segala putusan Majelis Permusyawaratan Rakyat ditetapkan dengan suara terbanyak.Dalam pasal 3 dinyatakan, Majelis Permusyawaratan Rakyat menetapkan Undang-Undang Dasar dan garis-garis besarhaluan negara.Pasal 6 juga menyangkut kewenangan MPR dimana tertulis, Presiden dan Wakil Presiden dipilih oleh Majelis Permusyawaratan Rakyat dengan suara yang terbanyak.Dan dalam pasal 9 juga diatur bahwa sebelum memangku jabatan sebagai Presiden dan Wakil Presiden, keduanya harus bersumpah atau berjanji dengan sungguh-sungguh dihadapan Majelis Permusyawaratan Rakyat.Untuk mengetahui sistem pemerintahan yang dianut UUD 1945, perlu memperhatikan penjelasan UUD 1945 yang menguraikan secara singkat sistem penyelenggaraan kekuasaan negara yang dianut oleh Undang-Undang Dasar tersebut. Dalam penjelasan itu diuraikan tentang sistem pemerintahan negara yang terdiri dari tujuh prinsip pokok, yaitu sebagai berikut :Prinsip negara berdasar atas hukum (rechtsstaat) bukan atas kekuasaan belaka (machtstaat) dan prinsip sistem konstitusinal (berdasarkan atas konstitusi) tidakberdasar atas absolutisme.Prinsip selanjutnya adalah kekuasaan negara tertinggi di tangan Majelis Permusyawaratan Rakyat (MPR). Penjelasan UUD 1945 menerangkan bahwa kedaulatan dipegang oleh suatu badan, bernama MPR sebagai penjelmaan seluruh rakyat Indonesia.Majelis ini menetapkan UUD dan garis-garis besar haluan negara, mengangkat Kepala Negara (Presiden) dan Wakil Presiden.Majelis inilah yang memegang kekuasaan negara yang tertinggi, sedang Presiden harus menjalankan haluan negara menurut garis-garis besar yang telah ditetapkan MPR.Presiden yang diangkat oleh MPR, bertunduk dan bertanggung jawab kepada Majelis.Ia adalah mandataris dari Majelis. Presiden tidak "neben" tetapi "untergeordnet" kepada Majelis. MPR adalah Lembaga Tertinggi Negara (TAP
MPR NO.III/1978), sedangkan lembaga negara yang lainnya adalah merupakan Lembaga Tinggi Negara dan Presiden memegang posisi sentral karena dialah mandatarisMPR.

Prinsip selanjutnnya, Presiden adalah penyelenggara pemerintah negara tertinggi di bawah Majelis.Penjelasan UUD 1945 menguraikan bahwa di bawah MPR, Presiden adalah penyelenggara pemerintah negara yang tertinggi dalam menjalankan pemerintahan negara.Kekuasaan dan tanggung jawab adalah ditangan Presiden (concentration of power and responsibility upon the presiden).Presiden adalah mandataris MPR, dia tunduk dan bertanggung jawab kepada MPR.Dengan posisi mandataris itulah Presiden memiliki diskresi kekuasaan dan kewenangan yang sangat besar.Di samping memegang kekuasaan eksekutif (executive power), Presiden juga sekaligus memegang kekuasaan legisltaf (legislative power). Meskipundemikian ditegaskan bahwakekuasaan Presiden sebagai kepala negara tidak tak terbatas. Presiden senantiasa dapat diawasi oleh DPR, dan Presiden harus memperhatikan sungguhsungguh suara DPR. Karena itu Presiden harus dapat bekerja bersama-sama dengan DPR, akan tetapi Presiden tidak bertanggungjawab kepada DPR.Menteri-menteri negara adalah pembantu Presiden dan tidak bertanggung jawab kepada DPR. Karena itu kedudukan menteri-menteri negara tidak tergantung DPR akan tetapi tergantung Presiden. Meskipun mereka adalah pembantu Presiden, tetapi Menteri-menteri negara bukan pegawai tinggi biasa, karena menteri-menteri itulah yang menjalankan kekuasaan pemerintah dalam praktek.Menteri-menteri negara memimpin departemen.Lebih lanjut, penjelasan UUD 1945 menguraikan bahwa kedudukan DPR adalah kuat. Di samping Presiden adalan Dewan Perwakilan Rakyat.DPR tidak dapat dibubarkan oleh Presiden. Setiap saat DPR dapat mengawasi Presiden, dan jika dalam pengawasan itu DPR menemukan bahwa Presiden telah melanggar haluan negara yang telah ditetapkan oleh UUD atau yang telah ditetapkan oleh MPR, maka MPR dapat diundang untuk mengadakan persidangan istimewa agar bisa 
meminta pertanggungan jawab kepada Presiden. Kewenangan DPR yang diatur dalam UUD 1945 sangat minim, yaitu memberi persetujuan atas undang-undang yang dibentuk Presiden (pasal 20 ayat1dan 2 jo pasal 5), memberi persetujuan atas PERPU (pasal 22), memberi persetujuan atas anggaran (pasal 23) dan persetujuan atas pernyataan perang, perdamaian dan perjanjian dengan negara lain yang dilakukan oleh Presiden. Kewenangan DPR untuk mengawasi pemerintah/Presiden dan kewenangan untuk meminta MPR mengadakan sidang istimewa untuk meminta pertanggungan jawab Presiden (fungsi kontrol) hanya diterangkan dalampenjelasan.Disamping itu UUD 1945, juga mengintrodusir badan-badan negara yang lain seperti Dewan Pertimbangan Agung (DPA), dan Badan Pemeriksa Keuangan (BPK).DPA hanya untuk memberi nasihat belaka kepada Presiden apakah diminta atau tidak diminta.Demikianlah sistem pemerintahan negara menurut UUD 1945 sebelum perubahan.

Dalam sistem seperti ini desain kelembagaan MPR merupakan lembaga negara terpenting karena lembaga ini adalah penjelmaan seluruh rakyat.Setelah itu adalah Presiden, karena Presiden adalah "mandataris" MPR.Dengan demikian kelembagaan negara dalam sistem pemerintahan ini terstruktur, yaitu MPR memegang kekuasaan negara tertinggi sebagai sumber kekuasaan negara dan dibawahnya adalah Presiden sebagai penyelenggara kekuasaan pemerintahan yang tertinggi di bawah MPR.Sistem seperti ini tidak menganut prinsip checks and balances, dan tidak mengatur pembatasan yang tegas penyelenggaraan kekuasaan negara antara lembaga negara.Karena kelemahan inilah dalampraktekketatanegaraan Indonesia banyak disalahgunakan dan ditafsirkan sesuai kehendak siapa yang memegang kekuasaan.Dengan demikian sistem perwakilan rakyat dalam periode UUD 1945, sebelum perubahan khususnya MPR memiliki kewenangan yang sangat besar, yaitu sepenuhnya melaksanakan kedaulatan rakyat dan dianggap sebagai penjelmaan seluruh rakyat Indonesia.
Desain Kelembagaan MPR Setelah Amandemen Undang-Undang Dasar 1945

Undang-Undang Dasar 1945 dalam perjalanannya telah mengalamiperubahan sebanyak empat kali pada tahun 1999, 2000, 2001, dan terakhir pada 2002. Dalam perubahannya itu, desain ketatanegaraan pun ikut berubah. Desain kelembagaan MPR dapat dilihat lebih lanjut dalam perubahan ketiga Undang-Undang Dasar 1945 dalam Pasal 3 mengenai wewenang MPR. Semula ketentuan tersebut tanpa ayat, kemudian dalam perubahan ditambah dengan empat ayat menjadi:Majelis Permusyawaratan Rakyatberwenang mengubah dan menetapkan Undang-UndangDasar, Majelis Permusyawaratan Rakyat melantik Presiden dan/atau WakilPresiden, Majelis Permusyawaratan Rakyat hanya dapat memberhentikan Presiden dan/ atau Wakil Presiden dalam masa jabatannya menurut Undang-Undang Dasar.Terhadap ketentuan baru di atas, ada beberapa hal yang perlu dilihat. Pengaturan tersebut dirumuskan dalam upaya menata ulang sistem ketatanegaraan yang optimal yang mengarah ke sistem checks and balances antar lembaga negara dalam kedudukan yang setara. Kemudian MPR tidak lagi menetapkan GBHN maupun dalam bentuk hukum (Tap MPR) dan tidak lagi memilih Presiden dan Wakil Presidenterkait dengan ketentuan baru hasil perubahan UUD 1945.Selanjutnya, MPR hanya berwenang untuk melantik Presiden dan Wakil Presiden terpilih. Berdasarkan ketentuan itu pula, MPR mempunyai tiga kewenangan sebagaimana yang ditetapkan dalam pasal 3 ayat (1), (2), dan (3) UUD 1945 hasil perubahan ketiga ditambah kewenangan yang termaktub dalam Pasal 8 ayat (2) perubahan ketiga, dan ayat(3) perubahankeempat.

\section{Sistem Kameral MPR Setelah Amandemen Undang-UndangDasar 1945}

Setelah perubahan Undang-Undang 1945, desain kelembagaan MPR juga mengalami perubahan yang dapat dikatakan cukup mendasar.Perubahan yang meniadakan kedudukan MPR sebagai lembaga tertinggi negara secara konseptual ingin menegaskan bahwa MPR bukan satu-satunya lembaga yang melaksanakan kedaulatan rakyat.Setiap lembaga yang mengemban tugas-tugas politik negara dan pemerintahan adalah 
pelaksana kedaulatan rakyat dan harus tunduk dan bertanggungjawab kepada rakyat.

Setelah diubah, pasal di atas berbunyi: "Majelis Permusyawaratan Rakyat terdiri atas anggota Dewan Perwakilan Rakyat dan anggota Dewan Perwakilan Daerah yang dipilih melalui pemilihan umum dan diatur lebih lanjut dengan undang- undang". Perubahan Pasal 2 ayat (1) menghapuskan unsur utusan golongan dan mengubah utusan daerah menjadi DPD.

Pada prinsipnya, kedua kamar majelis dalam sistem bikameral itu memiliki kedudukan yang sederajat. Satu sama lain tidak saling membawahi, baik secara politik maupun secara legislatif. Undang-undang tidak dapat ditetapkan tanpa persetujuan bersama yang biasanya dilakukan oleh suatu panitia bersama atau pun melalui sidang gabungan di antara kedua majelis itu.

Perubahan susunan MPR yang terdiri dari DPR dan DPD seolah mengarah pada pembentukan sistem dua kamar (bikameral).Tetapi dari susunan yang menyebutkan terdiri dari anggota-anggota DPR dan DPD, tidak tergambar konsep dua kamar. Dalam susunan dua kamar, bukan anggota yang menjadi unsur, tetapi badan yaitu DPR dan DPD, sehingga terkesan bahwa DPR dan DPD secara institusi bukan bagian dari MPR, melainkan anggota-anggota (dapat dikatakan secara individual) DPR dan DPD yang merangkap menjadi anggota MPR. Nama yang digagaskan untuk badan perwakilan dua kamar di Indonesia adalah tetap menggunakan Majelis Permusyawaratan Rakyat (MPR). Sebagai konsekuensi penggunaan nama MPR sebagai nama sistem dua kamar, maka MPR tidak lagi menjadi suatu lingkungan jabatan (lingkungan kerjatetap sendiri) yang memiliki lingkungan wewenang sendiri. Wewenang MPR (baru) melekat pada wewenang DPR dan DPD.Dengan adanya kewenangan yang demikian itu, maka dapat dipahami bahwa MPR berdiri sendiri di samping DPR dan DPD.Perubahan Undang-Undang Dasar 1945 terhadap pasal 3 rumusan baru, secara teoritis berarti terjadi perubahan fundamental dalam sistem ketatanegaraan Indonesia, yaitu sistem yang vertikal hirarkis dengan prinsip supremasi MPR menjadi horisontal fungsional dengan prinsip saling mengimbangi dan saling mengawasi antar lembaga negara (checks and balances).Akan tetapi, agaknya pembuat dan pengubah Undang-Undang Dasar 1945 diawal diadakannya DPD memang bertujuan untuk mengarahkan Indonesia menganut sistem bikameral. Hal ini dapat dilihat dari penjelasan Undang-Undang No. 22 Tahun 2003 tentang Susunan Dan Kedudukan Majelis Permusyawaratan Rakyat, Dewan Perwakilan Rakyat, Dewan Perwakilan Daerah, Dan Dewan Perwakilan Rakyat Daerah, sebagai berikut:Pembukaan Undang-Undang Dasar Negara Republik Indonesia Tahun 1945 mengamanatkan bahwa susunan Negara Republik Indonesia adalah negara yang berkedaulatan rakyat yang dalam pelaksanaannya menganut prinsip kerakyatan yang dipimpin oleh hikmat kebijaksanaan dalam permusyawaratan/perwakilan. Untuk mewujudkan hal tersebut perlu dibentuk lembaga permusyawaratan rakyat, lembaga perwakilan rakyat, dan lembaga perwakilan daerah yang mampu memperjuangkan aspirasi rakyat termasuk kepentingan daerah dalam rangka menegakkan nilai-nilai demokrasi, keadilan dan kesejahteraan rakyat dalam wadah Negara Kesatuan Republik Indonesia Berdasarkan pertimbangan tersebut di atas dipandang perluuntukmembentuk Undang-Undang tentang Susunan dan Kedudukan MPR, DPR, DPD, dan DPRD dalam rangka meningkatkan peran dan tanggung jawablembaga permusyawaratan dan perwakilan rakyat/daerah untuk mengembangkan kehidupan demokrasi, menjamin keterwakilan rakyat dan daerah dalam melaksanakan tugas dan kewenangannya, serta mengembangkan mekanisme checks and balances.Berdasarkan pembahasan yang telah dikemukakan, sistem checks and balances sangat identik dengan sistem bikameral.

Tetapi menurut penulis, sistem bikameral ini tidak dapat dikatakan murni begitu saja karena seperti yang penulis katakan sebelumnya bahwa sistem yang dianut Indonesia, menurut penulis, adalah sistem bikameral semu bertendensi unikameral.

\section{Kesimpulan dan Saran}

Dalam sistem ketatanegaraan Indonesia DPRdan DPD sebagai suatu lembaga merupakan kamar-kamar. Akan tetapi MPR tidak dibangun sebagai satu tempat yang menyatukan dua kamar tersebut, melainkan membentuk kamar atau ruangan barudengan menarik anggota dari DPR dan DPD tetapi bukan institusinya. Dengan demikian MPR di Indonesia saat ini menganut 
sistem unikameral karena MPR merupakan kamar sendiri yang terlepas dari institusi DPR dan DPD. DPR dan DPD tidak secara lembaga sebagai anggota MPR hanya anggota DPR dan anggota DPDlah yang menjadi anggota MPR yang masing-masing memiliki hak kewenangan yang sama dalam kedudukannya sebagai MPR. Karena itulah susunan lembaga perwakilan kita setelah perubahan ini secara teori tidak dapat dikatakan sebagai sistem lembaga perwakilan dua kamar (bicameral system). Desain MPR di Indonesia sebenarnya ingin diarahkan kepada sistem bikameral. Hal ini terlihat dari sistem pemilihan anggota DPR dan DPD yang dipilih secara langsung oleh rakyat dalam pemilu sehingga memiliki mandat yang samadari rakyat. Selain itu, sistem bikameral ini dapat terwujud dengan baik apabila posisi MPR yang memiliki kewenangan insidentil tidak dijadikan lembaga tetap dan merupakan gabungan dari DPR dan DPD sebagai institusi dengan kewenangan DPD disetarakan dengan DPR. Ketidakjelasan sistem kameral yang dianut

Majelis Permusyawaratan Rakyat setelah perubahan Undang-Undang Dasar 1945 terjadi karena ketimpangan pengaturan kekuasaan antara Dewan Perwakilan Rakyat dan Dewan Perwakilan Daerah serta mengenai Majelis Permusyawaratan Rakyat itusendiri. Hal tersebut menjadikan sistem kameral MPRadalah unikameral karena MPR tidak menjadi rumah yang menyatukan kamar DPR dan DPD.

MPR yang merupakan join session DPR dan DPD tidak perlu permanen, sehingga lebih tepat pimpinan MPR ad hoc dan diposisikan sebagai forum saja, tidak perlu sekertariat dan pimpinan yangterpisah agar anggaran negara untuk pembiayaan Ketua MPR, wakil MPR beserta seluruh dan jajarannya tidak perlu menggeluarkan biaya tambahan dari negara.
Daftar Pustaka

Buku

A.B. Kusuma. Lahirnya Undang-Undang Dasar 1945 (Memuat Salinan Dokumen Otentik Badan Oentoek Menyelidiki Oesaha2 Persiapan Kemerdekaan).Badan Penerbit Fakultas Hukum UI. Jakarta, 2004

A. Hamid S. Attamimi. Peranan Keputusan Presiden Republik Indonesia Dalam Penyelenggaran Pemerintahan Negara.Disertasi. UI, Jakarta, 1990,

A.G. Pringgodigdo. Sedjarah Singkat Berdirinja Negara Republik Indonesia.

cet. I. Pustaka Indonesia,Surabaya, 1958.

Abu Daud Busroh dan Abu Bakar Busroh..Azasazas Hukum Tata Negara.Ghalia Surabaya, Jakarta. 1991.

Bagir Manan. DPR.DPD.dan MPR dalam UUD 1945 Baru. FH UII Press. Yogyakarta, 2003.

Jimly Asshiddiqie..KONSTITUSI DAN KONSTITUALISME INDONESIA.Sinar Grafika. Jakarta, 2014.

S. T Kansil. Hukum Antartata Pemerintahan. Jakarta: Airlangga. Dahlan Thaib. etal. 2011. Teori dan Hukum Konstitusi.Rajawali Pers. Jakarta, 1986.

Fatmawati..Struktur dan Fungsi Legislasi Parlemen dengan Sistem Multikameral: Studi Perbandingan antara Indonesia dan Berbagai Negara. UIPress Jakarta, 2010.

Jimly Asshiddiqie.Pergumulan Peran Pemerintah dan Parlemen Dalam Sejarah Telaah Perbandingan Konstitusi Berbagai Negara.UI Press,Jakarta,1996.

King Faisal Sulaiman. Sistem Bikameral dalam Spektrum Lembaga Parlemen Indonesia. UII Press ,Yogyakarta, 2013

Moh. Mahfud MD. Dasar dan Strutur Ketata Negaraan Indonesia. Edisi Revisi. PT InekaCipta. Jakarta, 2001.

Ni'matul Huda.Hukum Tata Negara Indonesia. Raja Grafindo Persada. Jakarta,2006. 
Tô-râ: Volume 5 Nomor 1, April 2019, Fernando Silalahi, hal. 1-10

Parlin M. Mangunsong.Konvensi

Ketatanegaraan Sebagai Salah Satu

Sarana Perubahan UUD.

Alumni.Bandung, 1992

Pusat Studi Hukum dan Kebijakan.Semua Harus Terwakili; Studi mengenai Reposisi MPR.DPR. dan Lembaga Kepresidenan di Indonesia. Jakarta, 2000

Tim Penyusun Naskah Komprehensif Proses dan Hasil Perubahan UUD 1945. 2008. Naskah Komprehen- sif Perubahan Undang-Undang Dasar 1945 Neg- ara Republik Indonesia Tahun 1945:Sekertariat Jendral dan Kepaniteraan MahkamahKonstitusi. Jakarta.

PeraturanPerundang-Undangan

Undang-undang Dasar 1945 dan Amandemen, Pus- taka Sandro, Jakarta, 2014

Undang-undang UNDANG-UNDANG NOMOR 2 TAHUN 2018 TENTANG MPR DPR DPRD DAN

DPD tentang Perubahan Kedua atas Undang- undang RI Nomor 17 Tahun 2014, Citra Umbara Bandung, 2018. 